\title{
Synthesis, characterization and evaluation of antimicrobial and cytotoxic activities of biogenic silver nanoparticles synthesized from Streptomyces xinghaiensis OF1 strain
}

\author{
Magdalena Wypij ${ }^{1}$ Joanna Czarnecka ${ }^{2}$ - Magdalena Świecimska ${ }^{1} \cdot$ Hanna Dahm ${ }^{1}$ Mahendra Rai $^{3}$. \\ Patrycja Golinska ${ }^{1}$ iD
}

Received: 21 June 2017 / Accepted: 30 December 2017 / Published online: 5 January 2018

(c) The Author(s) 2018. This article is an open access publication

\begin{abstract}
We report synthesis of silver nanoparticles (AgNPs) from Streptomyces xinghaiensis OF1 strain, which were characterised by UV-Vis and Fourier transform infrared spectroscopy, Zeta sizer, Nano tracking analyser, and Transmission electron microscopy. The antimicrobial activity of AgNPs alone, and in combination with antibiotics was evaluated against bacteria, namely Escherichia coli, Pseudomonas aeruginosa, Staphylococcus aureus and Bacillus subtilis, and yeasts viz., Candida albicans and Malassezia furfur by using micro-dilution method. The minimum inhibitory concentration (MIC) and minimum biocidal concentration of AgNPs against bacterial and yeast strains were determined. Synergistic effect of AgNPs in combination with antibacterial and antifungal antibiotics was determined by FIC index. In addition, MTT assay was performed to study cytotoxicity of AgNPs alone and in combination with antibiotics against mouse fibroblasts and HeLa cell line. Biogenic AgNPs were stable, spherical, small, polydispersed and capped with organic compounds. The variable antimicrobial activity of AgNPs was observed against tested bacteria and yeasts. The lowest MIC $\left(16 \mu \mathrm{g} \mathrm{ml}^{-1}\right)$ of AgNPs was found against P. aeruginosa, followed by C. albicans and M. furfur (both $32 \mu \mathrm{g} \mathrm{ml}^{-1}$ ), B. subtilis and E. coli (both $64 \mu \mathrm{g} \mathrm{ml}^{-1}$ ), and then S. aureus and Klebsiella pneumoniae $\left(256 \mu \mathrm{g} \mathrm{ml}^{-1}\right)$. The high synergistic effect of antibiotics in combination with AgNPs against tested strains was found. The in vitro cytotoxicity of AgNPs against mouse fibroblasts and cancer HeLa cell lines revealed a dose dependent potential. The $\mathrm{IC}_{50}$ value of AgNPs was found in concentrations of 4 and $3.8 \mu \mathrm{g} \mathrm{ml}^{-1}$, respectively. Combination of AgNPs and antibiotics significantly decreased concentrations of both antimicrobials used and retained their high antibacterial and antifungal activity. The synthesis of AgNPs using S. xinghaiensis OF1 strain is an eco-friendly, cheap and nontoxic method. The antimicrobial activity of AgNPs could result from their small size. Remarkable synergistic effect of antibiotics and AgNPs offer their valuable potential in nanomedicine for clinical application as a combined therapy in the future.
\end{abstract}

Keywords Streptomycetes · Biogenic silver nanoparticles · Antimicrobials - Antibacterial activity - Antifungal activity · Synergism $\cdot$ Cytotoxicity

\section{Introduction}

Patrycja Golinska golinska@umk.pl

1 Department of Microbiology, Nicolaus Copernicus University, Lwowska 1, 87100 Torun, Poland

2 Department of Biochemistry, Nicolaus Copernicus University, Lwowska 1, 87100 Toruń, Poland

3 Nanobiotechnology Lab, Department of Biotechnology, SGB Amravati University, Amravati, Maharashtra 444602, India
Due to the extensive application of nanomaterials in medicine, food, agriculture, electronics, energy, etc. their global demand is growing significantly. Silver nanoparticles (AgNPs) are structures at less than $100 \mathrm{~nm}$ with unique physical, chemical and biological characteristics. Specific biological activity of AgNPs which results from their physicochemical properties and high surface area to volume ratio have attracted considerable attention globally (Mude et al. 2009). 
Nanoparticles are now considered as viable antimicrobial agent and seem to have tremendous potential to solve the problem of microbial multidrug resistance (Rai et al. 2012; Franci et al. 2015) and microbial biofilm formation (Mallevre et al. 2016). Considering limitations of antibiotic therapy and severe side effects of current antimicrobial drugs, there is an urgent need to develop new class of therapeutic agents with better biocompatibility and efficiency.

The biogenic nanoparticles have been found to be active against a wide range of Gram-negative and Gram-positive bacteria such as Escherichia coli, Vibrio cholerae, Pseudomonas aeruginosa, Salmonella typhi, Listeria monocytogenes, Staphylococcus aureus and Bacillus cereus as well as against fungi including Candida albicans, Candida tropicalis, Malassezia furfur and Trichophyton rubrum (Morones et al. 2005; Birla et al. 2009; Priyaragini et al. 2013; Anasane et al. 2016; Wypij et al. 2017). The enhanced antimicrobial activity of antibiotics in combination with biogenic AgNPs against $E$. coli, $P$. aeruginosa and $S$. aureus and fungi such as $C$. albicans, $C$. tropicalis and dermatophytes causing superficial mycoses, namely $M$. furfur and T. rubrum was also observed (Birla et al. 2009; Anasane et al. 2016; Wypij et al. 2017). Therefore, nanoparticles have huge potential for application in medicine (Firdhouse and Lalitha 2015). Moreover, biological synthesis of AgNPs is an easy, efficient and eco-friendly approach as compared to physical or chemical methods (Devi et al. 2012; Rai et al. 2015). In the present study, we selected actinobacterial strain for synthesis of biogenic nanoparticles as these microorganisms are known to be important producers of most natural bioactive compounds, mainly antibiotics and antimetabolites (Bérdy 2005; Newman and Cragg 2007; Olano et al. 2009a, b).

Therefore, the aims of the present study were: (i) synthesize and characterize biogenic AgNPs using actinobacterial strain Streptomyces xinghaiensis OF1, (ii) study antimicrobial activity alone and in combination with commonly used antibiotics and antifungal agents, and (iii) evaluate in vitro cytotoxicity against mouse fibroblast and cancer HeLa cell line.

\section{Materials and methods}

\section{Isolation of OF1 strain from sediment sample}

The actinobacterial OF1 strain was isolated from sediment samples of Lonar Crater of Maharashtra, India. The actinobacterium was isolated by serial dilution method as described by Golinska et al. (2013), albeit pH 8.5. Strain was maintained on halophilic nutrient agar (Atlas 2010) slants and as a spore and hyphal fragments in $20 \%$ glycerol (v/v) at $-80{ }^{\circ} \mathrm{C}$

\section{Molecular identification of OF1 strain}

The actinobacterial OF1 strain was identified as $S$. xinghaiensis OF1 strain on the basis of 16S rRNA gene sequence. The search for the closest phylogenetic neighbours based on 16S rRNA gene similarity was performed using the EzTaxon server (http://eztaxon-e.ezbiocloud. net/; Kim et al. 2012). The DNA extraction, PCR amplification and sequencing reactions were performed as previously described by Golinska et al. (2013) and Rathod et al. (2016).

\section{Synthesis of AgNPs from S. xinghaiensis OF1 strain}

The actinobacterial S. xinghaiensis OF1 strain, was cultured in Erlenmeyer flasks containing $100 \mathrm{ml}$ of halophilic nutrient broth ( $\mathrm{pH} \mathrm{8.5)} \mathrm{and} \mathrm{incubated} \mathrm{in} \mathrm{the} \mathrm{orbital} \mathrm{shaker}$ (150 r.p.m.) at $27 \pm 1{ }^{\circ} \mathrm{C}$ for one week. The cell biomass was harvested by centrifugation at $6000 \times g$ for $10 \mathrm{~min}$ and washed thrice with sterile distilled water to remove the attached media components. The cell biomass was resuspended in $100 \mathrm{ml}$ sterile distilled water, incubated at $27 \pm 1{ }^{\circ} \mathrm{C}$ for $48 \mathrm{~h}$ and then separated by centrifugation $6000 \times g$ for $10 \mathrm{~min}$. Supernatant was filtered by $0.45 \mu \mathrm{m}$ cellulose filter, combined with $\mathrm{AgNO}_{3}$ solution (final concentration $0.001 \mathrm{~mol} \mathrm{l}^{-1}$ ) and incubated at room temperature for 2-3 days. The cell free supernatant without silver nitrate was used as control.

Biosynthesized AgNPs were preliminary detected by colour change of the reaction mixture from colourless to dark-brown, which indicated the formation of AgNPs, and then confirmed by UV-Visible spectroscopy analysis (Nano Drop ND2000, Thermo Scientific, USA) at a resolution of $1 \mathrm{~nm}$ by scanning the absorbance spectra in a wavelength range of $200-800 \mathrm{~nm}$. The standard AgNPs (Sigma-Aldrich, size $20 \mathrm{~nm}$ and concentration $20 \mu \mathrm{g} \mathrm{ml}^{-1}$ ) as well as silver nitrate $\left(0.001 \mathrm{~mol} \mathrm{l}^{-1}\right)$ were also used for UV-Vis spectroscopic analysis.

Solution of biosynthesized AgNPs was treated with $\mathrm{NaCl}$ solution ( $1 \% \mathrm{v} / \mathrm{v})$ to remove unreacted $\mathrm{Ag}$ ions. Biosynthesized nanoparticles present in the solution were centrifuged at $12,000 \times g$ for $30 \mathrm{~min}$, dried at $40{ }^{\circ} \mathrm{C}$ and maintained at $4{ }^{\circ} \mathrm{C}$. The mass of biosynthesized AgNPs was estimated. Proper concentrations of AgNPs were obtained by dissolving AgNPs in sterile, deionized water, medium broth or phosphate-buffered saline (PBS). The AgNPs were active against bacteria and fungi up to 6 months. 


\section{Physico-chemical studies of biogenic AgNPs from $S$. xinghaiensis OF1 strain}

The size and topology of biosynthesized AgNPs were characterized by Transmission electron microscopy TEM (FEI Tecnai F20 X-Twintool, USA) after dropping a small volume of AgNP solution on a carbon coated copper grids (400 $\mu \mathrm{m}$ mesh size). The data were calculated by Statistica Software (StatSoft, USA).

The average particle size and size distribution of synthesized AgNPs from $S$. xinghaiensis OF1 strain were analysed by the NTA system LM20 (NanoSight Ltd, UK) after dilution with the nuclease free water. The $0.5 \mathrm{ml}$ of sample was injected onto the sample chamber and observed through LM20.

The stability of biosynthesized AgNPs was estimated based on measurement of their zeta potential using Zeta sizer (Malvern Instruments Ltd, UK). Water was used as a dispersion medium. The refractive index of 1.3 , viscosity of $0.8(\mathrm{cP})$, dielectric constant of 78.5 and a temperature of $-25^{\circ} \mathrm{C}$ were applied and total 12 zeta runs were performed.

The presence of possible biomolecules responsible for the reduction of the $\mathrm{Ag}^{+}$ions and the capping agents over the surface of biosynthesized AgNPs were analysed by Fourier-Transform Infrared Spectroscopy (FTIR; Perkin-Elmer FTIR-2000, USA). The FTIR measurements in the wavelength range of $4000-400 \mathrm{~cm}^{-1}$ at a resolution of $4 \mathrm{~cm}^{-1}$ were performed after combination of the dry powder of biosynthesized Ag-nanoparticles with dry $\operatorname{KBr}(1: 100$, w/w).

\section{Minimum inhibitory concentrations (MICs) and minimum biocidal concentrations (MBCs) of AgNPs synthesized from S. xinghaiensis OF1 strain against pathogenic bacteria and yeasts}

The biosynthesized AgNPs were evaluated against Grampositive bacteria, namely $S$. aureus (ATCC 6538) and $B$. subtilis (PCM 2021), and Gram-negative bacteria E. coli (ATCC 8739), P. aeruginosa (ATCC 10145) and Klebsiella pneumoniae (ATCC 700603), and against yeasts viz., $C$. albicans (ATCC 10231) and M. furfur (DSM 6170).

To determine the MIC of AgNPs, which is defined as the lowest concentration of AgNPs at which there is no visible growth of bacteria or fungi, the broth micro-dilution method recommended by Clinical Laboratory Standards Institute (CLSI) was used (Wayne and Clinical and Laboratory Standards Institute 2012). The assay was performed using 96-well microtiter plates in triplicate. The Tripticase Soy Broth (TSB, Becton Dickinson) and Sabouraud Dextrose Broth (SDB, Becton Dickinson) were used for bacterial and fungal growth, respectively. The SDB supplemented with olive oil $\left(2.5 \mathrm{ml} \mathrm{l}^{-1}\right)$ was used for $M$. furfur growth. The final concentration $5 \times 10^{5}$ c.f.u. $\mathrm{ml}^{-1}$ of bacteria or fungi was maintained in each well of microtitre plate. The different concentrations (from 0.016 to $1024 \mu \mathrm{g} \mathrm{ml}^{-1}$ ) of AgNPs were prepared. The positive control (broth mixed with microbial inoculum) and negative control (sterile noninoculated broth) were also maintained. Microbial inoculum density was estimated by colony counts. Briefly, the microbial inoculum $\left(5 \times 10^{5}\right.$ c.f.u. $\left.\mathrm{ml}^{-1}\right)$ was diluted with appropriate broth (1:1000) and $100 \mu \mathrm{l}$ was then spread on the surface of Tripticase Soy Agar (TSA, Becton Dickinson) or Sabouraud Dextrose Agar (SDA, Becton Dickinson). After incubation, the presence of approximately 50 colonies indicate an inoculum density of $5 \times 10^{5}$ c.f.u. $\mathrm{ml}^{-1}$. Inoculated microtitre plates were incubated at $37^{\circ} \mathrm{C}$ for $24 \mathrm{~h}$ (bacteria and $C$. albcans) or for $48 \mathrm{~h}$ (M. furfur). The MIC values were then estimated visually.

The minimum biocidal (bactericidal, fungicidal) concentrations (MBCs) of AgNPs against microorganisms, which is defined as the lowest concentration of antimicrobial agent that prevented growth of $>99.9 \%$ microbial cells were also determined.

After incubation, $100 \mu \mathrm{l}$ of each test sample was spread onto antimicrobial agent free medium (TSA for bacteria or SDA for C. albicans or SDA with olive oil for M. furfur). Plates were incubated at $37{ }^{\circ} \mathrm{C}$ for 24 or $48 \mathrm{~h}$ and observed for microbial growth.

\section{Antibiotic susceptibility test for bacteria and yeasts}

The susceptibility assay of bacteria to standard antibiotics such as ampicillin, kanamycin and tetracycline; and fungi to amphotericin B, fluconazole and ketoconazole was performed using microdilution method according to CLSI (Wayne and Clinical and Laboratory Standards Institute 2012). The assay was made in triplicate in 96-well microtitre plates as described previously for AgNPs. The antibiotics were tested in concentration range of $0.016-1024 \mu \mathrm{g} \mathrm{ml}^{-1}$. The TSB and SDB were used as diluents for bacteria and fungi, respectively. The final microbial density in each well was $5 \times 10^{5}$ c.f.u. $\mathrm{ml}^{-1}$. The MICs of antibiotics were determined visually. The MBCs of antibiotics were determined as described above for AgNPs.

\section{Biocompatibility index (BI) of AgNPs}

BI of AgNPs is defined as ratio of the mean values of $\mathrm{IC}_{50}$ of AgNPs on 3T3 and HeLa cells and concentration of AgNPs causing $3 \log _{10}$ reduction in microbial growth (99.9\%). A BI higher than 1 indicates that tested compound possess effective microbicidal activity and relatively low cytotoxicity, whereas a BI lower than 1 indicates antimicrobial agent with relatively high cytotoxicity (Müller and Kramer 2008). In the present studies, minimal 
biocidal concentrations (MBCs) were used for determination of $\mathrm{BI}$ as such concentrations caused $99.9 \%$ reduction of microbial growth.

\section{Antimicrobial activity of antibiotics in combination with biosynthesized AgNPs (FIC index determination)}

The activity of combination of antimicrobial agents was tested by checkerboard titration method (Saiman 2007) in 96-well microtitre plates (in triplicate). The final concentration of bacteria and fungi in each well was $5 \times 10^{5}$ c.f.u. $\mathrm{ml}^{-1}$. The trypticase soy broth (TSB, Becton Dickinson) or Sabouraud dextrose broth (SDB, Becton Dickinson) was used as diluents for bacterial and fungal strains, respectively. The positive and negative controls were maintained. The microtitre plates were incubated at $37^{\circ} \mathrm{C}$ for 24 or $48 \mathrm{~h}$ (M. furfur) to determine the microbial growth inhibition (visually).

Concentrations of antimicrobial and AgNPs used for determination of FIC index were as follows: $2 \times$ MICs, $1 \times$ MICs, 1/2 MICs, 1/4 MICs, 1/8 MICs, 1/16 MICs.

Based on the data obtained,the fractional inhibitory concentration (FIC) index was determined. The FIC index was calculated by comparing the value of the MIC of each agent alone with the combination-derived MIC. The combination of antimicrobial agents that resulted in at least fourfold reduction in the MIC (1/4 MIC) compared with the MICs of agents alone demonstrated synergistic efficacy (FIC $\leq 0.5$ ). FICs in the $>0.5-1.0$ range are considered to be non-synergistic or additive. FICs from 1 to 4 are defined as indifferent, while those of $>4$ are antagonistic (Doern 2014).

FIC index formula:

FIC $=($ MIC of AgNPs in combination with antibiotic $) /$

(MIC AgNPs alone)

+ (MIC of antibiotic in combination with AgNPs)/

(MIC of antibiotic alone).

\section{Scanning electron microscopy (SEM) analysis of $E$. coli and C. albicans after treatment with AgNPs}

SEM (Quanta 3D FEG, Fei, USA) was used for observations of bacterial and fungal cells after treatment with AgNPs. Microbial inoculum $\left(5 \times 10^{5}\right.$ c.f.u. $\left.\mathrm{ml}^{-1}\right)$ was combined with AgNP solution (MIC values of AgNPs against E. coli and C. albicans were used) and incubated for $24 \mathrm{~h}$. The samples were then dropped on a carbon-coated copper grids ( $400 \mu \mathrm{m}$ mesh size) and dried at room temperature before analysis.

\section{Cytotoxic activity of AgNPs}

The biogenic AgNPs synthesized from S. xinghaiensis OF1 strain were used for in vitro cytotoxicity assay against mouse fibroblasts (3T3) and HeLa cell line.

\section{Cell culture}

3T3 fibroblasts and HeLa cell line were cultured according to the manufacturer's protocol under sterile conditions in presence of $4.9 \% \mathrm{CO}_{2}$ at $37{ }^{\circ} \mathrm{C}$. After thawing, cells were cultured until they reached sub-confluent state. The cells were then detached using $0.25 \%$ trypsin solution and seeded into 24 -well plates $\left(3 \times 10^{3}\right.$ cells per well) for further experiments.

\section{Cytotoxicity evaluation}

The cytotoxic activity of AgNPs was evaluated in vitro, using the mouse 3T3 fibroblasts and HeLa cell line in triplicate. The cell viability and proliferative potential based on their metabolic activity were determined with MTT (3-(4,5-dimethylthiazolyl-2)-2,5-diphenyltetrazolium bromide) assay. The adherent culture medium was replaced with medium containing different concentrations $\left(1-100 \mu \mathrm{g} \mathrm{ml}^{-1}\right.$ ) of AgNPs and incubated for $24 \mathrm{~h}$. Subsequently, the cells were washed with PBS buffer and incubated with MTT reagent $\left(1 \mathrm{mg} \mathrm{ml}^{-1}\right)$ at $37^{\circ} \mathrm{C}$ for $30 \mathrm{~min}$. The obtained formazan crystals were dissolved in $1 \mathrm{ml}$ of DMSO. The plates were then read spectrophotometrically at a wavelength of $570 \mathrm{~nm}$. The cells were also observed microscopically (Inverted Phase Contrast Microscope Motic AE31 with Moticam and Motic software, Europe).

The percentage growth inhibition was calculated using the formula below:

$\%$ Cell inhibition $=100-\{(\mathrm{At}-\mathrm{Ab}) /(\mathrm{AcAb})\} \times 100$

where At is the absorbance value of test compound, $\mathrm{Ab}$ is absorbance value of blank and Ac is the absorbance value of control.

\section{Cytotoxic activity of antibiotics}

The assay was performed as described above for AgNPs. Antibiotic concentrations used were in the range of $0.016-256 \mu \mathrm{g} \mathrm{ml}^{-1}$. Estimation of percent cell viability was calculated as previously.

\section{Cytotoxicity of combined antimicrobial agents}

Combined antimicrobial agents (AgNPs and proper antibiotic) in concentrations of FIC (given in Table 2), which were 
found to be active against growth of selected bacterial and fungal strains, were tested for cytotoxicity towards 3T3 and HeLa cells. Cytotoxicity assay was preformed according to details given above for AgNPs. The percent of cell viability was calculated as previously.

\section{Results}

\section{Molecular identification of actinobacterial OF1 strain}

Nearly complete 16S rRNA gene sequence of the isolate OF1 (1414 nucleotides) was determined (GenBank accession number: KY 523106). Isolate was shown to be most closely related to $S$. xinghaiensis $\mathrm{S} 187^{\mathrm{T}}$ sharing a 16S rRNA gene sequence similarity with the closest phylogenetic neighbour of $98.3 \%$, a value that corresponds to 24 nucleotide differences per 1411 locations.

\section{Biosynthesis of AgNPs from S. xinghaiensis OF1 strain}

The dark-brown colour of the cell filtrate of strain OF1 after treatment with $1 \mathrm{mM}$ aqueous solution of $\mathrm{AgNO}_{3}$ was observed, which confirmed the synthesis of AgNPs. Further, the synthesized AgNPs were characterized by UV-Vis spectroscopy, which revealed narrow peak with a maximum absorbance at $420 \mathrm{~nm}$ (Fig. 1).

\section{Physico-chemical properties of biogenic AgNPs from S. xinghaiensis OF1 strain}

TEM analysis of AgNPs synthesized from S. xinghaiensis OF1 strain revealed the presence of spherical and polydispersed nanoparticles in the size range of 5-20 nm. At some places the aggregation of nanoparticles were also observed (Fig. 2).

In the present experiment, the nanaoparticle tracking analysis revealed average size of biosynthesized AgNPs of $64( \pm 49) \mathrm{nm}$ and their concentration as $2.7 \times 10^{7}$ particles $\mathrm{ml}^{-1}$ (Fig. 3).

The zeta potential measurements revealed that the biosynthesized AgNPs were found to be negatively charged $(-15.7 \mathrm{mV})$.

The FTIR analysis of AgNPs synthesized from strain OF1 showed total five absorbance bands at 3432, 2925, 1631, 1385 and $1033 \mathrm{~cm}^{-1}$ (Fig. 4).

\section{Minimum inhibitory concentrations (MICs) and minimum biocidal concentrations (MBCs) of AgNPs from S. xinghaiensis OF1 strain against pathogenic bacteria and fungi}

The biosynthesized AgNPs from S. xinghaiensis OF1 strain exhibited highest inhibitory activity against $P$. aeruginosa, followed by $C$. albicans and $M$. furfur, and then against $B$. subtilis and E. coli. K. pneumoniae and S. aureus were found to be much less sensitive to biosynthesized AgNPs. The MIC values were recorded as follows: 16, 32, 32, 64, 64 and $256 \mu \mathrm{g} \mathrm{ml}^{-1}$, respectively. The minimum biocidal concentration (MBC) of AgNPs was found to be $32 \mu \mathrm{g} \mathrm{ml}^{-1}$ for P. aeruginosa, $48 \mu \mathrm{g} \mathrm{ml}^{-1}$ for $M$. furfur, $64 \mu \mathrm{g} \mathrm{ml}^{-1}$ for $E$. coli and B. subtilis, $256 \mu \mathrm{g} \mathrm{ml}^{-1}$ for K. pneumoniae and $384 \mu \mathrm{g} \mathrm{ml}^{-1}$ for $S$. aureus. MBCs of AgNPs were not recorded for $C$. albicans in tested concentration range (Table 1).

Tested bacteria were most sensitive to tetracycline, followed by kanamycin and ampicillin, while $C$. albicans to amphotericin B, and M. furfur to fluconazole.

Biosynthesized AgNPs revealed much higher antibacterial activity than ampicillin ( $>1024 \mu \mathrm{g} \mathrm{ml}^{-1}$ ) against all Gram-negative bacteria and than kanamycin $\left(512 \mu \mathrm{g} \mathrm{ml}^{-1}\right)$ against E. coli, and P. aeruginosa. However, Gram-positive bacteria, namely $S$. aureus and $B$. subtilis were more susceptible to tested antibiotics in comparison with biosynthesized AgNPs. Similarly, AgNPs from OF1 strain were more active ( 64 and $16 \mu \mathrm{g} \mathrm{ml}^{-1}$ ) against $E$. coli and $P$. aeruginosa than kanamycin (> 256 and $64 \mu \mathrm{g} \mathrm{ml}^{-1}$, respectively). Biosynthesized AgNPs were found to be more active against C. albicans than fluconazole and ketoconazole (MIC both $\left.>1024 \mu \mathrm{g} \mathrm{ml}^{-1}\right)$ but not than amphotericin B $\left(0.25 \mu \mathrm{g} \mathrm{m}^{-1}\right)$. Similarly, M. furfur was more susceptible to fluconazole than to AgNPs but more resistant to amphotericin B and ketoconazole than to AgNPs (Table 1).

\section{Efficacy of AgNPs in combination with antimicrobials against bacteria and yeasts}

The results of the combination assay are presented in Table 2. Sixteen out of twenty-one antimicrobial agent combinations showed high synergistic effect against tested bacteria and fungi. The FIC index for those combinations was found to be 0.12 . Such FIC index value indicates that microbial growth was inhibited in the presence of 1/16 of MIC of both antimicrobials (AgNPs and antimicrobial agent), when compared to antimicrobials used alone. Combination of AgNPs and antibiotics against $P$. aeruginosa revealed indifferent effect on bacterial growth (FIC of 2.0), while combination of amphotericn B and fluconazole with AgNPs against $M$. furfur demonstrated non-synergistic or additive effect (FIC of 1.0) (Table 2). 
Table 1 MIC and MBC values $\left(\mu \mathrm{g} \mathrm{ml}^{-1}\right)$ of antibiotics and biogenic AgNPs synthesized from Streptomyces xinghaiensis OF1 strain against bacteria and yeasts evaluated by using method of CLSI, and biocompatibility index (BI) of AgNPs

\begin{tabular}{|c|c|c|c|c|c|c|c|c|c|c|}
\hline \multirow[t]{2}{*}{ Tested microorganism } & \multirow[t]{2}{*}{ MIC of AgNPs } & \multirow[t]{2}{*}{ MBC of AgNPs } & \multicolumn{3}{|c|}{ MIC of antibiotics } & \multicolumn{3}{|c|}{ MBC of antibiotics } & \multicolumn{2}{|c|}{$\mathrm{BI}$ of AgNPs } \\
\hline & & & AMP & $\mathrm{K}$ & $\mathrm{TE}$ & AMP & $\mathrm{K}$ & $\mathrm{TE}$ & $3 \mathrm{~T} 3$ & $\mathrm{HeLa}$ \\
\hline $\begin{array}{l}\text { Escherichia coli } \\
\text { ATCC } 8739\end{array}$ & 64 & 64 & $>1024$ & 512 & 64 & $>1024$ & $>1024$ & 256 & 0.06 & 0.06 \\
\hline $\begin{array}{l}\text { Klebsiella pneumoniae } \\
\text { ATCC } 700603\end{array}$ & 256 & 256 & $>1024$ & 192 & 32 & $>1024$ & 512 & 640 & 0.016 & 0.015 \\
\hline $\begin{array}{l}\text { Pseudomonas aerugi- } \\
\text { nosa ATCC } 10145\end{array}$ & 16 & 32 & 384 & 64 & 32 & $>1024$ & 256 & 96 & 0.125 & 0.12 \\
\hline $\begin{array}{l}\text { Staphylococcus aureus } \\
\text { ATCC } 6538\end{array}$ & 256 & 384 & 1 & 8 & 4 & 64 & 16 & 256 & 0.01 & 0.01 \\
\hline $\begin{array}{l}\text { Bacillus subtilis } \\
\text { PCM } 2021\end{array}$ & 64 & 64 & 0.064 & 2 & 0.125 & 0.125 & 2 & 48 & 0.06 & 0.06 \\
\hline \multirow[t]{2}{*}{ Tested microorganism } & \multirow[t]{2}{*}{ MIC of AgNPs } & \multirow[t]{2}{*}{ MBC of AgNPs } & \multicolumn{3}{|c|}{ MIC of antibiotics } & \multicolumn{3}{|c|}{ MBC of antibiotics } & \multicolumn{2}{|c|}{ BI of AgNPs } \\
\hline & & & $\mathrm{AMB}$ & FLU & $\mathrm{KCA}$ & AMB & FLU & $\mathrm{KCA}$ & $3 \mathrm{~T} 3$ & $\mathrm{HeLa}$ \\
\hline $\begin{array}{l}\text { Candida albicans } \\
\text { ATCC } 10231\end{array}$ & 32 & $>1024$ & 0.25 & $>1024$ & $>1024$ & 0.5 & $>1024$ & $>1024$ & 0.01 & 0.01 \\
\hline $\begin{array}{l}\text { Malassezia furfur } \\
\text { DSM } 6170\end{array}$ & 32 & 48 & $>1024$ & 4 & $>1024$ & $>1024$ & 96 & $>1024$ & 0.083 & 0.08 \\
\hline
\end{tabular}

$M I C$ minimum inhibitory concentration, $M B C$ minimum biocidal concentration, $A M P$ ampicillin, $K$ kanamycin, $T E$ tetracycline, $A M B$ amphotericin B, FLU fluconazole, $K C A$ ketoconazole, $B I$ biocompatibility index $\left(\mathrm{IC}_{50} / \mathrm{rf}\right), r f$ at least $3 \log _{10}(99.9 \%)$ reduction of microbial growth

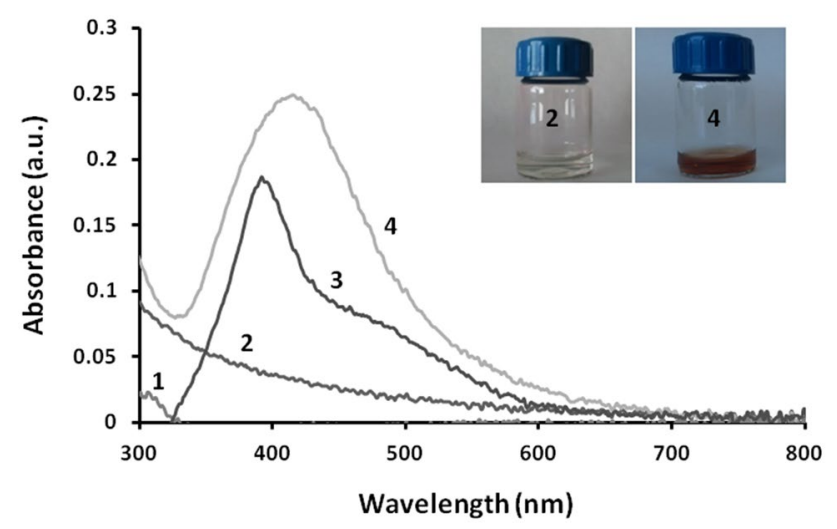

Fig. 1 UV-Visible spectrum of silver nanoparticles synthesized from Streptomyces xinghaiensis $\mathrm{OF} 1$ strain. $\mathrm{AgNO}_{3}(1)$, control (2), standard AgNPs (3), and experimental (4)

SEM analysis of E. coli and C. albicans cells after treatment with biosynthesized AgNPs are presented in Fig. 5. The high accumulation of AgNPs around surface of treated bacterial and fungal cells was observed after $24 \mathrm{~h}$ of incubation.

The biosynthesized AgNPs from S. xinghaiensis OF1 strain were subjected to cytotoxicity on mouse fibroblasts (3T3) and HeLa cell line. The dose dependent effect of AgNPs against eukaryotic cells was observed. The mouse fibroblasts viability after treatment with $1-5,10$ and $20 \mu \mathrm{g} \mathrm{ml}^{-1}$ of AgNPs was found to be 85.5, 61.1, 61.6, 50.5, 18.3, 6.5 and 6.2\%, while HeLa cells 93.2, 77.4, 64.3,

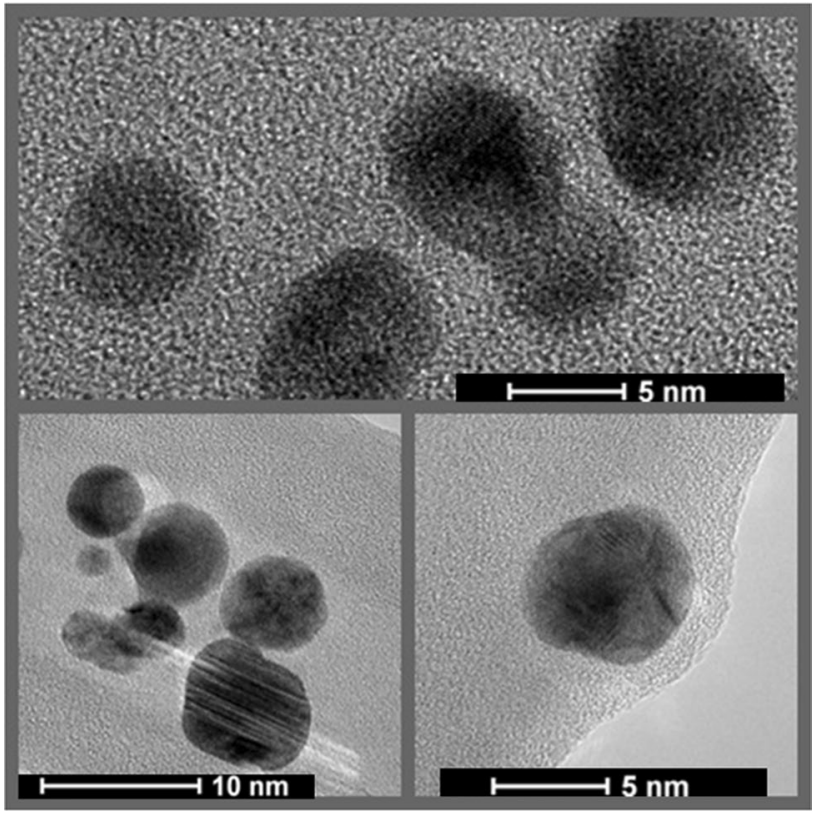

Fig. 2 Transmission electron micrograph of silver nanoparticles synthesized from Streptomyces xinghaiensis OF1 strain

50.0, 21.4, 10.45 and $11.9 \%$, respectively (Figs. 6, 7). The $\mathrm{IC}_{50}$ value of AgNPs was found to be 4 and $3.8 \mu \mathrm{g} \mathrm{ml}^{-1}$, respectively. The relatively high cytotoxicity of AgNPs was confirmed by biocompatibility index (BI) determination as its values were found to be much lower than 1 (Table 2). 


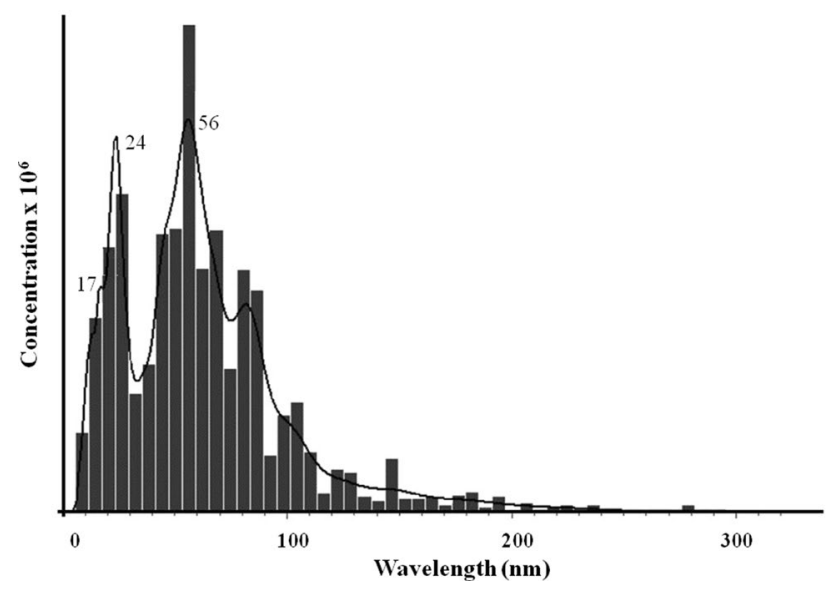

Fig. 3 Nanotracking analysis of silver nanoparticles synthesized from Streptomyces xinghaiensis OF1 strain

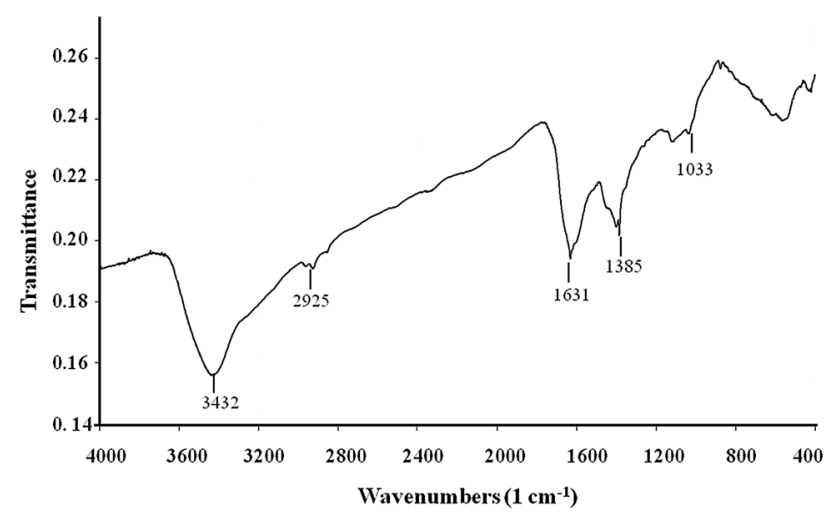

Fig. 4 Fourier transform infrared spectroscopy analysis of AgNPs synthesized from Streptomyces xinghaiensis OF1 strain. Absorbance bands: $3432,2925,1631,1385$ and $1033 \mathrm{~cm}^{-1}$

Generally, no toxicity or low toxicity of antibiotics was noticed against mouse fibroblasts (3T3) and HeLa cell line in test concentration range $\left(0.016-256 \mu \mathrm{g} \mathrm{ml}^{-1)}\right.$. There was no toxic effect of kanamycin, amphotericin B, fluconazole and ketoconazole on HeLa cells in tested concentration range, while $\mathrm{IC}_{50}$ of ampicillin and tetracycline was found to be at concentrations of 196 and $256 \mu \mathrm{g} \mathrm{ml}^{-1}$, respectively. Similarly, nontoxic effect of kanamycin, tetracycline, amphotericin B and ketoconazole was observed on 3T3 cells, whereas $\mathrm{IC}_{50}$ of ampicillin and fluconazole at concentration of 128 and $196 \mu \mathrm{g} \mathrm{ml}^{-1}$, respectively.

The cytotoxicity of AgNPs combined with selected antibacterial and antifungal antibiotics confirmed that four doubling reduction of both antimicrobial dosages caused reduction their cytotoxicity towards mammalian cells to value equal to $\mathrm{IC}_{50}$ of AgNPs used alone (Figs. 8, 9).

\section{Discussion}

\section{Synthesis of AgNPs from S. xinghaiensis OF1 strain}

In the present study, a colour change of reaction mixture resulted from excitation of surface plasmon resonance vibration of AgNPs present in the reaction mixture (Rai et al. 2015; Shanmugaiah et al. 2015) and was previously observed by many researchers (Kim et al. 2011; Golinska et al. 2015; Wypij et al. 2017). The UV-Visible spectroscopy is one of the most widely used techniques for structural characterization of nanoparticles (Annamalai and Nallamuthu 2016). The presence of absorbance peak in the range of 380-450 nm clearly indicates the formation of AgNPs in the solution (Ghorbani 2013).

\section{Physico-chemical characterization of AgNPs synthesized from $S$. xinghaiensis OF1 strain}

Biosynthesized nanoparticles were similar to those reported by Wypij et al. (2017). Authors reported presence of small (4-24 nm), spherical and polydispersed AgNPs synthesised from actinobacterial strain. However, other studies on synthesis of AgNPs from actinobacteria revealed fabrication of bigger NPs of $55 \mathrm{~nm}$ (Rathod et al. 2016) or $44 \mathrm{~nm}$ (Składanowski et al. 2016), and from fungi (Phoma gardeniae) of $88 \mathrm{~nm}$ (Rai et al. 2015). Moreover, TEM characterization of biosynthesized AgNPs revealed that the edges of the nanoparticles were lighter than their centers, which indicates that nanoparticles were capped with biomolecules (e.g. proteins) (Annamalai and Nallamuthu 2016). Generally, it has been found that reducing the size of AgNPs enhances their stability and biocompatibility (Kim et al. 2011). From the above observations, it has been concluded that actinobacteria have potential for synthesis of small particles with large surface area.

The average size and concentration of biosynthesized AgNPs was also estimated by using nano tracking analysis (NTA). The NTA is based on light scattering and Brownian motion properties in order to measure the good sizing accuracy and comparatively narrow scatterings from monodispersed samples (Potara et al. 2015).

The difference in the size of biosynthesized AgNPs analysed by TEM (5-20 nm) and NTA (64-69 $\mathrm{nm}$ ) resulted from fact that both techniques are based on different physical principles. During TEM analysis dried particles are measured and results present diameter of their metallic core only, whereas the NTA measure the hydrodynamic radius of nanoparticles in the solution and obtained nanoparticle size is always larger (Rai et al. 2015).

The zeta potential measurements, which revealed negative charge of biosynthesized AgNPs from OF1 strain 
Table 2 Fractional inhibitory concentration (FIC) index determined for AgNPs and antibiotics against bacteria and yeasts

\begin{tabular}{|c|c|c|c|c|c|c|}
\hline \multirow[t]{3}{*}{ Tested microorganism } & \multicolumn{6}{|c|}{ FIC index } \\
\hline & \multicolumn{2}{|c|}{ Ampicilin + AgNPs } & \multicolumn{2}{|c|}{ Kanamycin + AgNPs } & \multicolumn{2}{|c|}{ Tetracycline + AgNPs } \\
\hline & FIC & $\begin{array}{l}\text { Conc. of antimicrobial and } \\
\text { AgNPs used in determined } \\
\text { FIC }\left(\mu \mathrm{gl}^{-1}\right)\end{array}$ & FIC & $\begin{array}{l}\text { Conc. of antimicrobial and } \\
\text { AgNPs used in determined } \\
\text { FIC }\left(\mu \mathrm{g} \mathrm{ml}^{-1}\right)\end{array}$ & FIC & $\begin{array}{l}\text { Conc. of antimicrobial and } \\
\text { AgNPs used in determined FIC } \\
\left(\mu \mathrm{g} \mathrm{ml}^{-1}\right)\end{array}$ \\
\hline $\begin{array}{l}\text { Escherichia coli } \\
\text { ATCC } 8739\end{array}$ & $0.12^{\mathrm{a}}$ & $64+4$ & $0.12^{\mathrm{a}}$ & $32+4$ & 0.12 & $4+4$ \\
\hline $\begin{array}{l}\text { Klebsiella pneumoniae } \\
\text { ATCC } 700603\end{array}$ & $0.12^{\mathrm{a}}$ & $64+16$ & 0.12 & $12+16$ & 0.12 & $2+16$ \\
\hline $\begin{array}{l}\text { Pseudomonas aerugi- } \\
\text { nosa ATCC } 10145\end{array}$ & 2.0 & $768+32$ & 2.0 & $128+32$ & 2.0 & $64+32$ \\
\hline $\begin{array}{l}\text { Staphylococcus aureus } \\
\text { ATCC } 6538\end{array}$ & 0.12 & $0.0625+16$ & 0.12 & $0.5+16$ & 0.12 & $0.25+16$ \\
\hline $\begin{array}{l}\text { Bacillus subtilis } \\
\text { PCM } 2021\end{array}$ & 0.12 & $0.004+4$ & 0.12 & $0.125+4$ & 0.12 & $0.008+4$ \\
\hline \multirow[t]{3}{*}{ Tested microorganism } & \multicolumn{6}{|c|}{ FIC index } \\
\hline & \multicolumn{2}{|c|}{ Amphotericin B + AgNPs } & \multicolumn{2}{|c|}{ Fluconazole + AgNPs } & \multicolumn{2}{|c|}{ Ketoconazole + AgNPs } \\
\hline & FIC & $\begin{array}{l}\text { Conc. of antimicrobial and } \\
\text { AgNPs used in determined } \\
\text { FIC }\left(\mu \mathrm{gl}^{-1}\right)\end{array}$ & FIC & $\begin{array}{l}\text { Conc. of antimicrobial and } \\
\text { AgNPs used in determined } \\
\text { FIC }\left(\mu \mathrm{g} \mathrm{ml}^{-1}\right)\end{array}$ & FIC & $\begin{array}{l}\text { Conc. of antimicrobial and } \\
\text { AgNPs used in determined FIC } \\
\left(\mu \mathrm{g} \mathrm{ml}^{-1}\right)\end{array}$ \\
\hline $\begin{array}{l}\text { Candida albicans } \\
\text { ATCC } 10231\end{array}$ & 0.12 & $0.016+2$ & $0.12^{\mathrm{a}}$ & $64+2$ & $0.12^{\mathrm{a}}$ & $64+2$ \\
\hline $\begin{array}{l}\text { Malassezia furfur } \\
\text { DSM } 6170\end{array}$ & $1.0^{\mathrm{a}}$ & $1024+32$ & 1.0 & $4+32$ & $0.12^{\mathrm{a}}$ & $64+2$ \\
\hline
\end{tabular}

Reduction of AgNPs concentration after combined use with antibiotics to value $\leq \mathrm{IC}_{50}$ (about $4 \mu \mathrm{g} \mathrm{ml}^{-1}$ ) are highlighted in bold $\leq 0.5$ synergism; $>0.5-1.0$ non synergistic or additive effect; $\geq 1.0-2.0$ indifferent effect (Doern 2014)

${ }^{a}$ As the MIC was not determined in the wide concentration range of antibiotic (see Table 1), the highest concentration of antibiotic was used for FIC index determination

clearly confirmed their higher stability than those reported by Prakasham et al. (2012) who observed zeta potential of AgNPs synthesized from Streptomyces albidoflavus as $-8.5 \mathrm{mV}$. The higher the negative or positive zeta potential, the stronger the prevention of AgNPs from its aggregation (Muthuvel et al. 2014).

FTIR measurements of biogenic AgNPs from OF1 strain provided evidence of specific functional groups constituting organic molecules, which are responsible for the reduction of silver ions to AgNPs and stability of AgNPs (Sanghi and Verma 2009; Manivasagan et al. 2013). The absorbance peaks at $3432 \mathrm{~cm}^{-1}$ can be assigned to $\mathrm{N}-\mathrm{H}$ stretching vibration (Mohanta and Behera 2014; Shanmugaiah et al. 2015), whereas at $2925 \mathrm{~cm}^{-1}$ can be associated to $\mathrm{C}-\mathrm{H}$ stretching vibration-asym (Karthik et al. 2013). The band at $1631 \mathrm{~cm}^{-1}$ can be attributed to the $\mathrm{C}=\mathrm{C}$ stretching vibration (Annamalai and Nallamuthu 2016). The peak at $1385 \mathrm{~cm}^{-1}$ correspond to $\mathrm{C}-\mathrm{H}$ sym. deformation vibration (Deepa et al. 2013) and at $1033 \mathrm{~cm}^{-1}$ can be assigned to $\mathrm{C}-\mathrm{O}$ stretching vibration (Rai et al. 2015). Based on these results, it can be concluded that AgNPs were capped with organic compounds with amino bonds.

\section{Antimicrobial activity of AgNPs synthesized from $S$. xinghaiensis OF1 strain}

Nanoparticles are considered to be a viable substitute to antibiotics and appear to have a high potential to solve the problem of the rise of microbial multidrug-resistance (Vandeputte et al. 2012; Franci et al. 2015). In the present study also AgNPs synthesized from $S$. xinghaiensis OF1 strain demonstrated antimicrobial activity against all tested bacteria and yeasts.

It is well known that antimicrobial activity of metal nanoparticle depends on their size and shape (Pal et al. 2007; Sharma et al. 2009) as well as stability (Shrivastava et al. 2007). Smaller nanoparticles cause higher toxicity to microbial pathogens, as these nanoparticles probably diffuse more easily than larger ones (Panáček et al. 2006; Mohan et al. 2007). It is claimed that for nanoparticles to be effective 


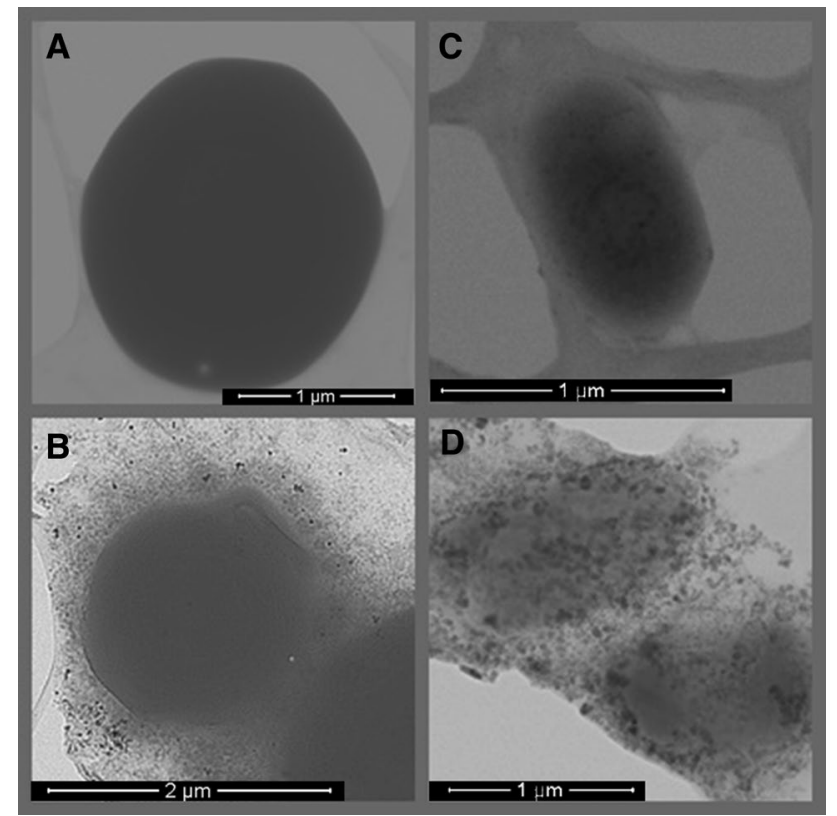

Fig. 5 SEM analysis of Candida albicans and Escherichia coli cells before and after treatment with silver nanoparticles. Upper panel is control and lower panel is microbial cells treated with AgNPs. $C$. albicans $(\mathbf{a}, \mathbf{b})$ and $E$. coli $(\mathbf{c}, \mathbf{d})$

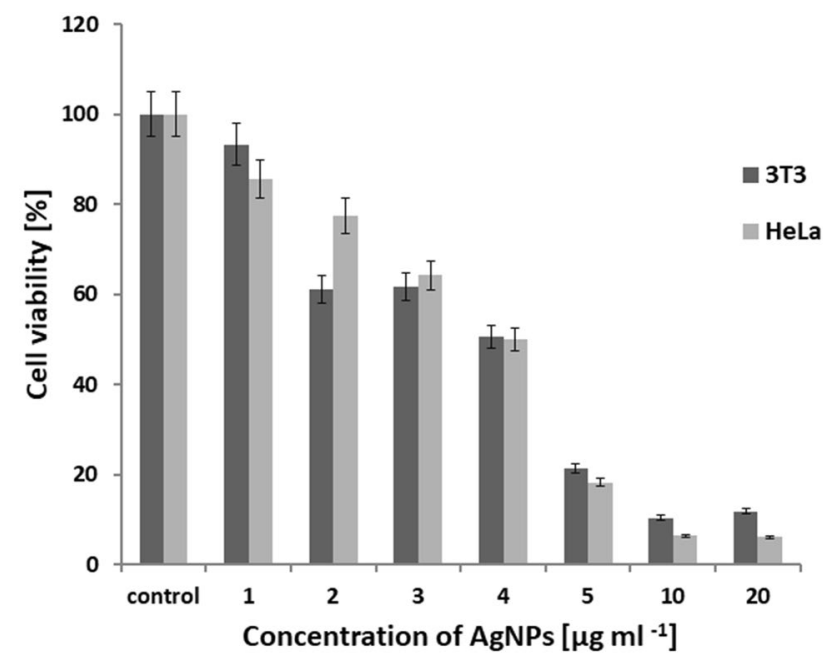

Fig. 6 Cytotoxic activity of AgNPs from Streptomyces xinghaiensis OF1 strain against mouse fibroblasts (3T3) and HeLa cell line

their size typically should be no larger than $50 \mathrm{~nm}$ (Dakal et al. 2016).

The AgNPs synthesized from S. xinghaiensis OF1 strain demonstrated more activity against Gram-negative bacteria and yeasts as compared to some selected antibiotics. Gurunathan and coworkers (2014) also reported higher antibacterial activity of AgNPs, which were synthesized from leaf extract of Allophylus cobbe against Pseudomonas
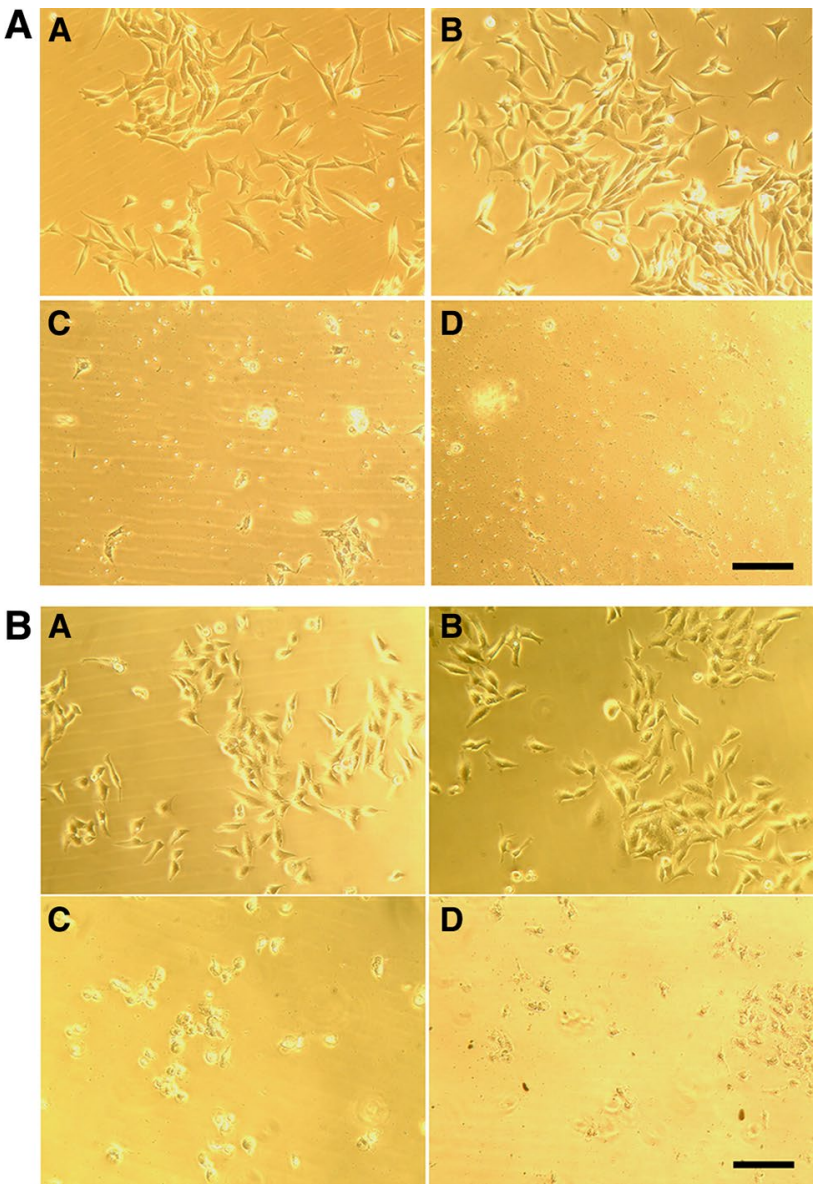

Fig. 7 Microscopic observations of mouse fibroblasts (A) and HeLa cells (B) after treatment with various concentrations of biosynthesized silver nanoparticles $\left(a 1 \mu \mathrm{g} \mathrm{ml}^{-1}, b 5 \mu \mathrm{g} \mathrm{ml}^{-1}, c 10 \mu \mathrm{g} \mathrm{ml}^{-1}, d\right.$ $20 \mu \mathrm{g} \mathrm{ml}^{-1}$ ). Scale bar $100 \mu \mathrm{m}$

aeruginosa, Shigella flexneri, S. aureus and Streptococcus pneumoniae than commercial antibiotics, namely ampicillin, chloramphenicol, erythromycin, gentamicin, tetracycline, and vancomycin. The MIC of AgNPs from OF1 strain against $E$. coli, $P$. aeruginosa and $B$. subtilis was found to be much lower than reported by Singh et al. (2013) who observed MIC of biogenic AgNPs against panel of Gramnegative bacteria (E. coli, Acinetobacter baumannii, Enterobacter aerogenes, P.aeruginosa, Salmonella typhimurium and Shigella sonneii) in the range of $150-600 \mu \mathrm{g} \mathrm{ml}^{-1}$, while against Gram-positive S. aureus and Streptococcus mutans $>1000 \mu \mathrm{g} \mathrm{ml}^{-1}$. Nasrollahi et al. (2011) reported higher antifungal activity of AgNPs against $C$. albicans than fluconazole and amphotericin B, but in our studies antifungal activity of amphotericin $B$ was found in much lower concentration than fabricated AgNPs. Moazeni et al. (2012) reported antifungal activity of mycogenic AgNPs from Trichophyton mentagrophytes against $C$. albicans. The MIC value against tested fungi was found to be $4 \mu \mathrm{g} \mathrm{ml}^{-1}$, 

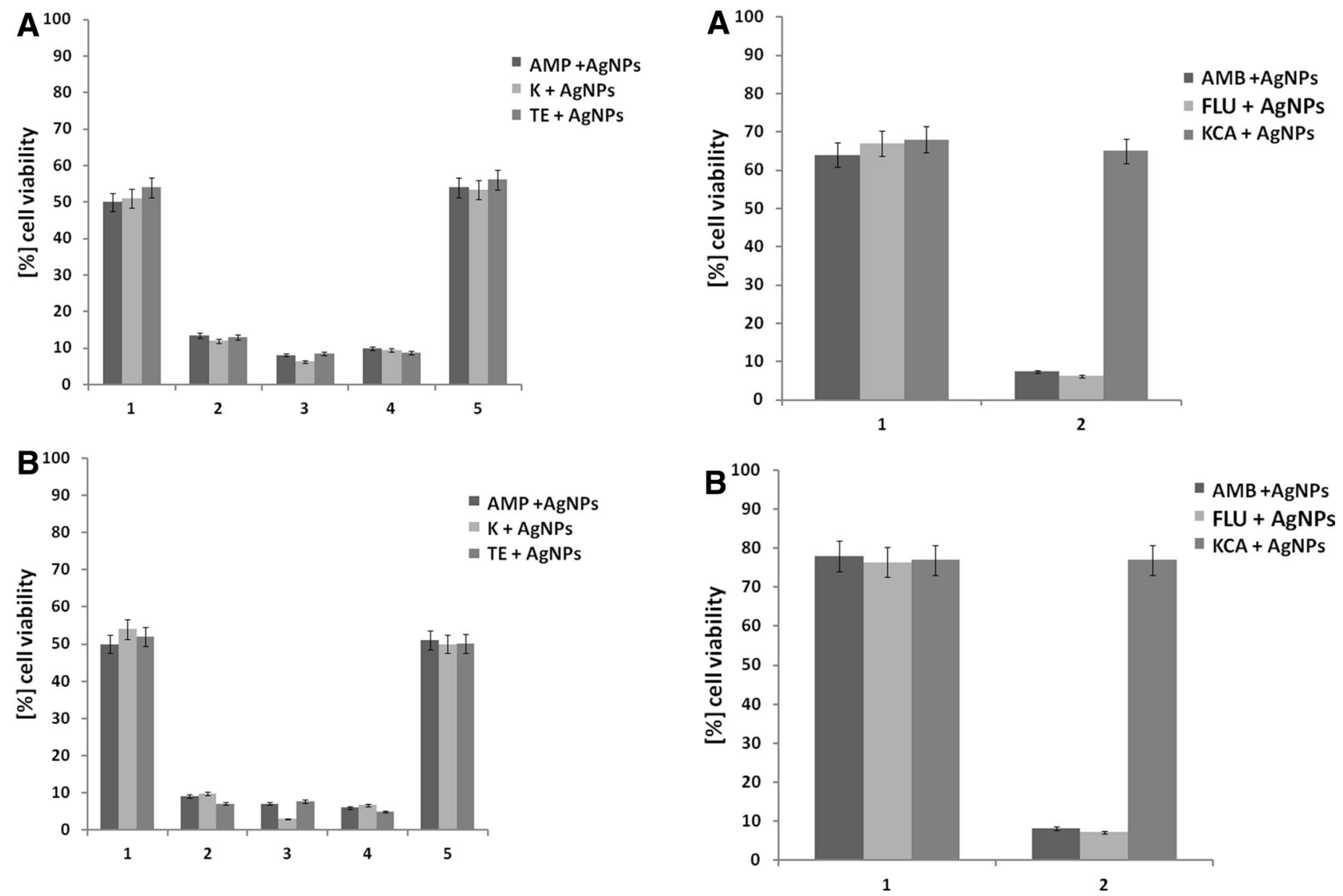

Fig. 8 Cytotoxic activity of combined antimicrobial agents (AgNPs and antibacterial antibiotics) against a mouse fibroblasts (3T3) and b HeLa cell line. Both antimicrobials were used at concentrations of their FIC (see Table 2): (1) $\left(4 \mu \mathrm{g} \mathrm{ml}^{-1}\right.$ of AgNPs $+64 \mu \mathrm{g} \mathrm{ml} \mathrm{g}^{-1}$ AMP or $32 \mu \mathrm{g} \mathrm{ml}^{-1} \mathrm{~K}$ or $\left.4 \mu \mathrm{g} \mathrm{ml}^{-1} \mathrm{TE}\right)$, (2) $\left(16 \mu \mathrm{g} \mathrm{m} \mathrm{m}^{-1}\right.$ of AgNPs $+64 \mu \mathrm{g} \mathrm{ml}^{-1}$ AMP or $12 \mu \mathrm{g} \mathrm{ml}^{-1} \mathrm{~K}$ or $2 \mu \mathrm{g} \mathrm{ml}^{-1} \mathrm{TE}$ ), (3) $\left(1 \mu \mathrm{g} \mathrm{ml} \mathrm{m}^{-1}\right.$ of AgNPs $+768 \mu \mathrm{g} \mathrm{ml} \mathrm{m}^{-1}$ AMP or $128 \mu \mathrm{g} \mathrm{ml} \mathrm{m}^{-1}$ $\mathrm{K}$ or $\left.64 \mu \mathrm{g} \mathrm{ml} l^{-1} \mathrm{TE}\right)$, (4) $\left(16 \mu \mathrm{g} \mathrm{ml} l^{-1}\right.$ of $\mathrm{AgNPs}+0.06 \mu \mathrm{g} \mathrm{ml} \mathrm{g}^{-1}$ AMP or $0.5 \mu \mathrm{g} \mathrm{ml}^{-1} \mathrm{~K}$ or $\left.0.25 \mu \mathrm{g} \mathrm{ml}^{-1} \mathrm{TE}\right)$, (5) $\left(4 \mu \mathrm{g} \mathrm{ml} \mathrm{m}^{-1}\right.$ of AgNPs $+0.004 \mu \mathrm{g} \mathrm{ml}^{-1}$ AMP or $0.125 \mu \mathrm{g} \mathrm{ml}^{-1} \mathrm{~K}$ or $0.008 \mu \mathrm{g} \mathrm{ml}^{-1}$ TE). AMP ampicillin, $K$ kanamycin, $T E$ tetracycline

thus eightfold lower than in the present study $\left(32 \mu \mathrm{ml}^{-1}\right)$. However, Anasane et al. (2016) showed higher MIC of AgNPs synthesized from actinobacterial strain against $C$. albicans and $C$. tropicalis $\left(40 \mu \mathrm{g} \mathrm{ml}^{-1}\right.$, both). The MIC value of AgNPs against M. furfur $\left(30 \mu \mathrm{g} \mathrm{ml}^{-1}\right)$ was similar to findings in the present study.

In general, biocidal concentration of AgNPs against Gram-negative bacteria was much lower than all test antibiotics. Similar findings were recorded for fungi, with exception of amphotericin B.

The AgNP exposure to microorganisms causes irreversible changes in cell wall structure resulting in its disruption and affects integrity of lipid bilayer, permeability of the cell membrane and proper regulation of transport activity through the plasma (Panáček et al. 2006; Ghosh et al. 2012; Chauhan et al. 2013). AgNPs can further penetrate inside

Fig. 9 Cytotoxic activity of combined antimicrobial agents (AgNPs and antifungal antibiotics) against a mouse fibroblasts (3T3) and b HeLa cell line. Both antimicrobials were used at concentrations of their FIC (see Table 2): (1) $\left(2 \mu \mathrm{g} \mathrm{ml}^{-1}\right.$ of AgNPs $+0.016 \mu \mathrm{g} \mathrm{m}{ }^{-1}$ AMB or $64 \mu \mathrm{g} \mathrm{ml}^{-1}$ FLU or $\left.64 \mu \mathrm{g} \mathrm{ml}^{-1} \mathrm{KCA}\right)$, (2) $\left(32 \mu \mathrm{g} \mathrm{m} l^{-1}\right.$ of AgNPs $+1024 \mu \mathrm{g} \mathrm{ml}^{-1}$ AMB or $4 \mu \mathrm{g} \mathrm{ml}^{-1}$ FLU, and $2 \mu \mathrm{g} \mathrm{ml}^{-1}$ of AgNPs and $\left.64 \mu \mathrm{g} \mathrm{ml}^{-1} \mathrm{KCA}\right)$. $A M B$ amphotericin B, FLU fluconazole, $K C A$ ketoconazole

the microbial cell and interact with cellular structures and biomolecules such as proteins, lipids, and DNA. Interactions with cellular structures and biomolecules have damaging effect on microbes (Morones et al. 2005; Jung et al. 2008; Rai et al. 2012). Silver ions, as a secondary oxidation process of AgNPs, contribute to the biocidal properties of AgNPs by affecting transport and release of potassium $\left(\mathrm{K}^{+}\right)$ions from the microbial cells (Morones et al. 2005; Manivasagan et al. 2013). The increase in membrane permeability may lead to more pronounced effects such as loss by leakage of cellular contents, including ions, proteins, reducing sugars and sometimes cellular energy reservoir (ATP) (Lok et al. 2006; Kim et al. 2011; Li et al. 2013).

The synergistic activity of AgNPs with antimicrobials was observed against B. subtilis, S. aureus E. coli and $K$. pneumoniae. Contrary to antibacterial studies, the reports on determination of antimicrobial effect of AgNPs in 
combination with antibiotics by estimation of FIC index are scarce. Disc diffusion assay is most widely used method. In particular, data related to antifungal activity of AgNPs combined with antifungal agents are limited Synergistic activity of AgNPs and antibiotics (e.g. ampicillin, chloramphenicol, gentamycin, kanamycin, neomycin) against $S$. aureus, including MRSA, Streptococcus mutans, E. coli, P. aeruginosa etc. have been reported (Prakasham et al. 2012; Muthuvel et al. 2014; Potara et al. 2015). Authors demonstrated various effects of AgNP and antibiotic combinations from synergistic to antagonistic. In the present study, the synergistic and non-synergistic effect of combination of biosynthesized AgNPs with antibiotics was recorded. Interestingly, the synergistic effect was also observed for ampicillin or kanamycin and AgNPs against E. coli or ampicillin and AgNPs against $K$. pneumoniae, even though MICs of those antibiotics were not determined for bacteria $\left(>1024 \mu \mathrm{g} \mathrm{ml}^{-1}\right)$. The use of the highest tested concentration of antibiotic resulted in high synergistic effect of combined antimicrobials against test strains. Similar effect was also noted for fluconazole and ketoconazole in presence of AgNPs against $C$. albicans or ketoconazole in combination with AgNPs against $M$. furfur.

Unlike above results, $P$. aeruginosa showed resistance to ampicillin and $M$. furfur to amphotericin B, and combination of antibiotic with AgNPs did not affect susceptibility of microbial cells to tested antimicrobial agents. The activity of combined antimicrobials was determined as indifferent and non-synergistic effect, respectively.

It is claimed that organic compounds present on the surface of biogenic AgNPs interact with the antibiotics, modifying the output properties. The enhanced antimicrobial effect of combination of AgNPs with antibiotics may be caused by a binding between an antibiotic and biogenic nanosilver. The tested antibiotic contain many hydroxyl and amino groups that can easily react with AgNPs by chelation. It is also postulated that AgNPs act as an antibiotic carrier, facilitating penetration into microbial cells and improve their antimicrobial action (Duran et al. 2011). Moreover, combination of AgNPs with antibiotic reduces the toxicity of both compounds toward human cells by decreasing the required dosage with enhanced antimicrobial properties, which was also observed in the present study. Authors also claimed that such combination restores the ability of the drug to kill bacteria that have acquired resistance to them (Allahverdiyev et al. 2011; Singh et al. 2013, 2015). Combined use of AgNPs and antibiotic/antifungal agent in the present studies supported above findings and proved that such combinations allow to reduce dosage of both antimicrobials and their toxicity toward mouse fibroblasts and HeLa cells.

\section{Cytotoxicity of AgNPs synthesized from S. xinghaiensis OF1 strain}

The in vitro study of cytotoxic efficacy of AgNPs synthesized from $S$. xinghaiensis $\mathrm{OF} 1$ strain on mouse fibroblasts (3T3) and HeLa cell line was high ( $\mathrm{IC}_{50}$ about $4 \mu \mathrm{gl}^{-1}$ ), which was also confirmed by biocompatibility index determination. However, other authors reported that concentration of AgNPs from actinobacterial strains required for reduction in viability by $50 \%$ HeLa cells was 200 or $100 \mu \mathrm{g} \mathrm{ml}^{-1}$ (Manivasagan et al. 2013; Rathod et al. 2016). The lower cytotoxic effect of actinobacterial synthesized $\mathrm{AgNPs}\left(\mathrm{IC}_{50}\right.$ value of $64.5 \mu \mathrm{g} \mathrm{ml}^{-1}$ ) against mouse fibroblasts (L929 cell line) was found in studies by Składanowski et al. (2016). HeLa cell lines are commonly used model, but it is well known that the cancer cells show lower sensitivity to cytotoxic conditions than the more physiologically relevant $3 \mathrm{~T} 3$ cell line. In our opinion, the inconsistencies between other researchers and data of the present study may arose due to the differences in experimental protocols and models (Julien et al. 2010; Nogueira et al. 2011).

Panáček et al. (2016) showed that in some cases combination of antibiotics with AgNPs at their concentrations equal to MIC values decreased cell viability from 85 to $71 \%$ when compared to untreated cells. Authors concluded that the cytotoxic effect was higher as a result of the additive cytotoxic effects of the antibiotics and AgNPs. The highest cytotoxic effect was detected for ampicillin/sulbactam, cefazolin, meropenem and chloramphenicol combined with AgNPs. We report that low concentrations of antibiotics and AgNPs slightly decreased the viability of cells (to 90-95\%) in comparison with the control cells depending on the antibiotics used.

On the basis of the results, we suggest that biogenic AgNPs have much potential for application as an antimicrobial agent in combination with antibiotics/antifungals. Combined therapy could significantly decrease concentration of both antimicrobials and remove the resistance of antibiotics to pathogenic microbes.

Acknowledgements This study was financed by Grant Nos. 2016/23/N/ NZ9/00247 and 2017/01/X/NZ8/00140 from National Science Centre $(\mathrm{NCN})$ in Poland.

\section{Compliance with ethical standards}

Conflict of interest All authors declare that they have no conflict of interest.

Ethical approval This article does not contain any studies with human participants or animals performed by any of the authors.

Informed consent Informed consent was obtained from all individual participants included in the study. 
Open Access This article is distributed under the terms of the Creative Commons Attribution 4.0 International License (http://creativecommons.org/licenses/by/4.0/), which permits unrestricted use, distribution, and reproduction in any medium, provided you give appropriate credit to the original author(s) and the source, provide a link to the Creative Commons license, and indicate if changes were made.

\section{References}

Allahverdiyev AM, Emrah SA, Malahat B, Cem BU, Cengiz K, Figen K, Rafailovich M (2011) Antileishmanial effect of silver nanoparticles and their enhanced antiparasitic activity under ultraviolet light. Int J Nanomed 6:2705-2714

Anasane N, Golinska P, Wypij M, Rathod D, Dahm H, Rai M (2016) Acidophilic actinobacteria synthesised silver nanoparticles showed remarkable activity against fungi-causing superficial mycoses in humans. Mycoses 59:157-166

Annamalai J, Nallamuthu T (2016) Green synthesis of silver nanoparticles: characterization and determination of antibacterial potency. Appl Nanosci 6:259-265

Atlas RM (2010) Handbook of microbiological media, 4th edn. CRC Press, Boston

Bérdy J (2005) Bioactive microbial metabolites. J Antibiot 58:1-26

Birla SS, Tiwari VV, Gade AK, Ingle AP, Yadav AP (2009) Fabrication of silver nanoparticles by Phoma glomerata and its combined effect against Escherichia coli, Pseudomonas aeruginosa and Staphylococcus aureus. Lett Appl Microbiol 48:173-179

Chauhan R, Kumar A, Abraham J (2013) A Biological Approach to the synthesis of silver nanoparticles with Streptomyces sp JAR1 and its antimicrobial activity. Sci Pharm 81:607-621

Dakal TC, Kumar A, Majumdar RS, Yadav V (2016) Mechanistic basis of antimicrobial actions of silver nanoparticles. Front Microbiol 7:1831. https://doi.org/10.3389/fmicb.2016.01831

Deepa S, Kanimozhi K, Panneerselvam A (2013) Antimicrobial activity of extracellularly synthesized silver nanoparticles from marine derived actinomycetes. Int J Curr Microbiol Appl Sci 2:223-230

Devi JS, Bhimba BV, Ratnam K (2012) In vitro anticancer activity of silver nanoparticles synthesized using the extract of Gelidiella sp. Int J Pharm Pharm Sci 4:710-715

Doern CD (2014) When does 2 plus 2 equal 5? A review of antimicrobial synergy testing. J Clin Microbiol 52:4124-4128

Duran N, Marcato PD, Duran M, Yadav A, Gade A (2011) Mechanistic aspects in the biogenic synthesis of extracellular metal nanoparticles by peptides, bacteria, fungi and plants. App Microbiol Biotechnol 3:1609-1624

Firdhouse MJ, Lalitha P (2015) Biosynthesis of silver nanoparticles and its applications. J Nanotechnol 2015:1-18. https://doi. org/10.1155/2015/829526

Franci G, Falanga A, Galdiero S, Palomba L, Rai M (2015) Silver nanoparticles as potential antibacterial agents. Molecules $20: 8856-8874$

Ghorbani HR (2013) Biosynthesis of silver nanoparticles by Escherichia coli. Asian J Chem 25:1247-1249

Ghosh S, Patil S, Ahire M, Kitture R, Kale S, Pardesi K (2012) Synthesis of silver nanoparticles using Dioscorea bulbifera tuber extract and evolution of its synergistic potential in combination with antimicrobial agents. Int J Nanomed 7:483-496

Golinska P, Wang D, Goodfellow M (2013) Nocardia aciditolerans sp nov, isolated from a spruce forest soil. Antonie Van Leeuwenhoek 103:1079-1088

Golinska P, Wypij M, Rathod D, Dahm H, Rai M (2015) Synthesis of silver nanoparticles from two acidophilic strains of Pilimelia columellifera subsp. pallida and their antibacterial activities. J Basic Microbiol 55:1-16
Gurunathan S, Han JW, Kwon DN, Kim JH (2014) Enhanced antibacterial and antibiofilm activities of silver nanoparticles against Gramnegative and Gram-positive bacteria. Nanoscale Res Lett 9:373

Julien DC, Richardson CC, Beaux MF, Mcllroy DN, Hill RA (2010) In vitro proliferating cell models to study cytotoxicity of silica nanowires. Nanomedicine 6:84-92

Jung WK, Koo HC, Kim KW, Shin S, Kim SH, Park YH (2008) Antibacterial activity and mechanism of action of the silver ion in Staphylococcus aureus and Escherichia coli. Appl Environ Microbiol 74:2171-2178

Karthik L, Kumar G, Kirthi AV, Rahuman AA, Rao KVB (2013)) Streptomyces sp. LK3 mediated synthesis of silver nanoparticles and its biomedical application. Bioproc Biosyst Eng 37:261-267

Kim SH, Lee HS, Ryu DS, Choi SJ, Lee DS (2011) Antibacterial activity of silver-nanoparticles against Staphylococcus aureus and Escherichia coli. Korean J Microbiol Biotechnol 39:77-85

Kim OS, Cho YJ, Lee K, Yoon SH, Kim M (2012) Introducing EzTaxon-e, a prokaryotic 16S rRNA gene sequence database with phylotypes that represent uncultured species. Int J Syst Evol Microbiol 62:716-721

Li J, Rong K, Zhao H, Li F, Lu Z, Chen R (2013) Highly selective antibacterial activities of silver nanoparticles against Bacillus subtilis. J Nanosci Nanotechnol 13:6806-6813

Lok CN, Ho CM, Chen R, He QY, Yu WY, Sun H (2006) Proteomic analysis of the mode of antibacterial action of silver nanoparticles. J Proteome Res 5:916-924

Mallevre F, Fernandes TF, Aspray TJ (2016) Pseudomonas putida biofilm dynamics following a single pulse of silver nanoparticles. Chemosphere 153:356-364

Manivasagan P, Venkatesan J, Senthilkumar K, Sivakumar K, Kim SK (2013) Biosynthesis, antimicrobial and cytotoxic effect of silver nanoparticles using a novel Nocardiopsis sp. MBRC-1. Bio Med Res Int 2013:1-9. https://doi.org/10.1155/2013/287638

Moazeni M, Rashidi N, Shahverdi AR, Noorbakhsh F, Rezaie S (2012) Extracellular production of silver nanoparticles by using three common species of dermatophytes: Trichophyton rubrum, Trichophyton mentagrophytes and Microsporum canis. Iranian Biomed J 16:52-58

Mohan YM, Lee K, Premkumar T, Geckeler KE (2007) Hydrogel networks as nanoreactors: a novel approach to silver nanoparticles for antibacterial applications. Polymer 48:158-164

Mohanta YK, Behera SK (2014) Biosynthesis, characterization and antimicrobial activity of silver nanoparticles by Streptomyces sp. SS2. Bioproc Biosys Eng 37:2263-2269

Morones JR, Elechiguerra LJ, Camacho A, Holt K, Kouri BJ (2005) The bactericidal effect of silver nanoparticles. Nanotechnol 16:2346-2353

Mude N, Ingle A, Gade A, Rai M (2009) Synthesis of silver nanoparticles using callus extract of Carica papaya: a first report. J Plant Biochem Biotechnol 18:83-86

Müller G, Kramer A (2008) Biocompatibility index of antiseptic agents by parallel assessment of antimicrobial activity and cellular cytotoxicity. J Antimicrob Chemother 61:1281-1287

Muthuvel A, Adavallan K, Balamurugan K, Krishnakumar N (2014) Biosynthesis of gold nanoparticles using Solanum nigrum leaf extract and screening their free radical scavenging and antibacterial properties. Biomed Prev Nutr 4:325-332

Nasrollahi A, Pourshamsian K, Mansourkiaee P (2011) Antifungal activity of silver nanoparticles on some of fungi. Int J Nano Dim 1:233-239

Newman DJ, Cragg GM (2007) Natural products as sources of new drugs over the last 25 years. J Nat Prod 70:461-477

Nogueira DR, Mitjans M, Infante MR, Vinardell MP (2011) Comparative sensitivity of tumor and non-tumor cell lines as a reliable approach for in vitro cytotoxicity screening of lysine-based 
surfactants with potential pharmaceutical applications. Int $\mathbf{J}$ Pharm 25:51-58

Olano C, Méndez C, Salas JA (2009a) Antitumor compounds from marine actinomycetes. Mar Drugs 7:210-248

Olano C, Méndez C, Salas JA (2009b) Antitumor compounds from actinomycetes from gene clusters to new derivatives by combinatorial synthesis. Nat Prod Rep 26:628-660

Pal S, Tak YK, Song JM (2007) Does the antibacterial activity of silver nanoparticles depend on the shape of the nanoparticle? A study of the Gram-negative bacterium Escherichia coli. Appl Environ Microbiol 27:1712-1720

Panáček A, Kvitek L, Prucek R, Kolar M, Vecerova R (2006) Silver colloid nanoparticles: synthesis, characterization, and their antibacterial activity. J Phys Chem B 110:16248-16253

Panáček A, Smékalová M, Kilianová M, Prucek R, Bogdanová K, Večeřová R, Kolář M, Havrdová M, Płaza GA, Chojniak J, Zbořil R, Kvítek L (2016) Strong and nonspecific synergistic antibacterial efficiency of antibiotics combined with silver nanoparticles at very low concentrations showing no cytotoxic effect. Molecules 21:26. https://doi.org/10.3390/molecules21010026

Potara M, Bawaskar M, Simon T, Gaikwad S, Licarete E (2015) Biosynthesized silver nanoparticles performing as biogenic SERSnanotags for investigation of $\mathrm{C} 26$ colon carcinoma cells. Colloids Surf B 133:296-303

Prakasham RS, Buddana SK, Yannam SK, Guntuku GS (2012) Characterization of silver nanoparticles synthesized by using marine isolate Streptomyces albidoflavus. J Microbiol Biotechnol 22:614-621

Priyaragini S, Sathishkumar SR, Bhaskararao KV (2013) Biosynthesis of silver nanoparticles using actinobacteria and evaluating its antimicrobial and cytotoxicity activity. Int J Pharm Sci 5:709-712

Rai MK, Deshmukh SD, Ingle AP, Gade AK (2012) Silver nanoparticles: the powerful nanoweapon against multidrug-resistant bacteria. J Appl Microbiol 112:841-852

Rai M, Ingle A, Gade A, Duarte MCT, Duran N (2015) Synthesis of silver nanoparticles by Phoma gardeniae and in vitro evaluation of their efficacy against human disease-causing bacteria and fungi. IET Nanobiotechnol 9:71-75

Rathod D, Golinska P, Wypij M, Dahm H, Rai M (2016) A new report of Nocardiopsis valliformis strain OT1 from alkaline Lonar crater of India and its use in synthesis of silver nanoparticles with special reference to evaluation of antibacterial activity and cytotoxicity. Med Microbiol Immunol 205:435-447

Saiman L (2007) Clinical utility of synergy testing for multidrug-resistant Pseudomonas aeruginosa isolated from patients with cystic fibrosis: 'the motion for'. Paediatr Resoir Rev 8:249-255

Sanghi R, Verma P (2009) Biomimetic synthesis and characterisation of protein capped silver nanoparticles. Bioresour Technol 100:501-504

Shanmugaiah V, Harikrishnan H, Al-Harbi NS, Shine K, Khaled JM (2015) Facile synthesis of silver nanoparticles using Streptomyces sp. VSMGT1014 and their antimicrobial efficiency. Dig J Nanomater Biostruct 10:179-187

Sharma VK, Yngard RA, Lin Y (2009) Silver nanoparticles: green synthesis and their antimicrobial activities. Adv Colloid Interface Sci 145:83-96

Shrivastava S, Bera T, Roy A, Singh G, Ramachandrarao P, Dash D (2007) Characterization of enhanced antibacterial effects of novel silver nanoparticles. Nanotechnol 18:225103-225111

Singh R, Wagh P, Wadhwani S, Gaidhani S, Kumbhar A (2013) Synthesis, optimization, and characterization of silver nanoparticles from Acinetobacter calcoaceticus and their enhanced antibacterial activity when combined with antibiotics. Int J Nanomed 8:4277-4290

Singh BR, Singh BN, Singh A, Khan W, Naqvi AH, Singh HB (2015) Mycofabricated biosilver nanoparticles interrupt Pseudomonas aeruginosa quorum sensing systems. Sci Rep 5:13719. https:// doi.org/10.1038/srep13719

Składanowski M, Golinska P, Rudnicka K, Dahm H, Rai M (2016) Evaluation of cytotoxicity, immune-compatibility and antibacterial activity of biogenic silver nanoparticles. Med Microbiol Immunol 205:603-613

Vandeputte P, Ferrari S, Coste AT (2012) Antifungal resistance and new strategies to control fungal infections. Int J Microbiol 2012:1-26. https://doi.org/10.1155/2012/713687

Wayne PA, Clinical and Laboratory Standards Institute (2012) Methods for dilution antimicrobial susceptibility tests for bacteria that grow aerobically: approved standard, 9th edn. Clinical and Laboratory Standards Institute, Wayne

Wypij M, Golinska P, Dahm H, Rai M (2017) Actinobacterial-mediated synthesis of silver nanoparticles and their activity against pathogenic bacteria. IET Nanobiotechnol 11:336-342 